\title{
Cîteva reflecții cu privire la starea traductologiei românești
}

\author{
Magda Jeanrenaud* \\ Facultatea de Litere, Universitatea „Alexandru Ioan Cuza”, Bd. Carol I 11, 700506 Iași, România
}

Despre articol
Istoric:
Primit 1 iunie 2015
Acceptat 18 iunie 2015
Publicat 17 iulie 2015
Cuvinte-cheie:
traductologie
practica traducerii
limbă centrală
limbă periferică
cîmp simbolic
globalizare

\begin{abstract}
Rezumat
Mi-am propus să examinez temeiurile a două „verdicte” contradictorii privind starea traductologiei românești, unul dat în 1998, în Encyclopedia of Translation Studies, celălalt într-o lucrare mai recentă, privind ,ideile și metaideile traductive românești”. Am încercat să arăt că actuala situație, pe care am prezentat-o pe larg, aşezînd în paralel trei momente-cheie din evoluția gîndirii traductologice în spațiul românesc, îndreptățește următoarea ipoteză: specificul actual al teoriilor traductologice în spațiul românesc decurge din existența a două circuite, unul academic și internațional, care urmărește înscrierea cercetării românești în direcțiile conturate la nivel european, asimilîndu-le mai mult sau mai puțin, și altul, intern, în care pozițiile exprimate în cadrul celui dintîi pătrund indirect, prin intermediul limbilor „centrale” și se manifestă sub forma unor afinități selective și elective, între cele două interacțiunea făcîndu-se sporadic, și mai ales prin intermediul altor limbi, și nu printr-un proces de interiorizare legat de limba română, adică limba spațiului gazdă.
\end{abstract}

„Nu ar trebui să trecem niciodată sub tăcere problema limbii în care se pune problema limbii și în care este tradus un discurs despre traducere”. ${ }^{1}$

Jacques Derrida

\section{Introducere}

Există o diferență semnificativă în proiectul abordării chestiunilor traductologice și, în special, a tradițiilor traductologice între prima și cea de-a doua ediție a cunoscutei Encyclopedia of Translation Studies (cea din 1998 și cea din 2009). Argumentînd necesitatea unei noi ediții, dar și pentru a putea reflecta interesele și prioritățile unei comunități științifice ce s-a lărgit și consolidat între timp, coordonatoarele volumului, Mona Baker și Gabriela Saldanha, par a-şi fi dat seama abia cînd o pregăteau (după cum rezultă din Introducere) că „traductologia a avut în mod tradițional o puternică orientare europocentrică, iar în unele părți ale lumii continuă să fie dominată de paradigme teoretice care-și au originile în Vest, ignorînd bogata și substanțial diferita experiență dinafara Europei și a Americii de Nord” (Baker \& Saldanha, 2011); dat fiind că disciplina și-a cîștigat un statut academic, de sine stătător, ar fi timpul, susţin editoarele, să se ia notă de creșterea interesului pentru abordările dinafara celor două spații culturale pentru a „reconsidera poziția și preocupările centrale ale disciplinei”, cu atît mai mult cu cît numărul lucrărilor dedicate acestei problematici a sporit, antrenînd o repoziționare pe plan internațional a traductologiei, capabilă să determine un nou echilibru, în care să se facă auzite și „voci” din spațiul asiatic, african, dar și din cel denumit de cele două editoare Middle East (formulă folosită și în cele două volume editate de Theo Hermans sub titlul Translating Others; Hermans, 2014). Cu alte cuvinte, noua ediție își propunea să prezinte traductologia în lumina unei tot mai evidente „multidisciplinarități” și să ia notă de vădita ei tendință de a „rupe cu originile sale exclusiv europocentrice”.

*Adresă de corespondență: mjeanrenaud@hotmail.com.

${ }^{1}$ Derrida (1998, p. 204). Traducerea acestui citat ne aparține, ca și traducerea celorlalte citate din prezentul studiu. 
Însă conceptul globalizant al „europocentrismului” mi se pare că ar fi meritat să fie, la rîndul său, supus unei minuțioase și îndelungate demontări, care să-i redea bogăția și varietatea: dacă în interiorul cîmpului cultural european rețelele de influență și cîmpurile de putere simbolice se structurează în jurul culturilor „mari”, difuzate de limbile „centrale”, atunci ar trebui examinate și reacțiile vizavi de traducere și gîndirea asupra acesteia ale culturilor „mici”, vehiculate de limbile „periferice”. Cu alte cuvinte, acest spațiu este departe de a fi unul omogen: dimpotrivă, el este traversat de tensiuni inegale, ce depind în mare măsură de culturile „mari”, vehiculate de limbile „centrale”, vizavi de care culturile „mici”, difuzate de limbile „periferice”, se poziționează neîncetat, în varii configurații, nu totdeauna obediente. Numindu-le „minorități invizibile” (Cronin, 2003, p. 139 și urm.) și asemănîndu-le ... cu Contele Dracula, cel care se privește în oglindă fără a se putea vedea vreodată, Michael Cronin atrăsese cu cîțiva ani mai devreme atenția asupra locutorilor ce vorbesc ceea ce el numește „limbi minoritare”, care, nici ele, nu reușesc să se regăsească în oglinda studiilor traductologice: ediția din 1998 a sus-numitului dicționar nu cuprinde nici o referință privitoare la „traducere și limbile minoritare” sau vreo abordare teoretică a acestei problematici, lucru cu atît mai paradoxal cu cît tocmai culturile dezvoltate de limbile „minoritare” sînt prin excelență culturi ale traducerii. Pe de altă parte, alți cercetători se întreabă tot mai insistent dacă, extinzîndu-l la spațiile geografice unde engleza este limba predominantă, conceptul de europocentrism mai este „cît de cît folositor” și dacă nu cumva poate fi „considerat teoretic redundant” (van Doorslaer \& Flynn, 2013, p. 5; Flynn, 2013b, p. 61-77).

Cît despre tradiția traductologică românească, regretatul Janos Kohn, care nu a mai putut aduce la zi prezentarea acesteia în ediția a doua, a dat, în ediția din 1998, un verdict succint, poate insuficient argumentat, lucru explicabil și prin spațiul restrîns alocat în Enciclopedie diverselor „tradiții”, dar care merită în orice caz examinat cu atenție. Autor, între altele, al unei lucrări de succes privind virtuțile compensatorii ale limbii române în traducere (Kohn, 1983), Janos Kohn formulează, în secțiunea axată pe „History and Traditions”, următorul diagnostic privind specificitatea teoriilor traductive românești: „În România, teoria traducerii rămîne strîns legată de practică” (Kohn, 1998, p. 539). Diagnosticul său este susținut de constatarea marii cantități de traduceri efectuate în perioada postbelică, ceea ce explică, după dînsul, și vizibila corelare a studiilor teoretice cu realizările practice. El mai remarcă și faptul că astfel de texte teoretice sînt adesea scrise de traducători profesioniști, însă exemplifică citînd opiniile unor mari scriitori români, care s-au ilustrat și în traducere (Blaga, 1957; Doinaș, 1965). Kohn nu uită să mai amintească totuși și existența unor lucrări de tip academic, centrate pe o perspectivă traductologică cu marcată orientare lingvistică, nu fără a sublinia că „numărul studiilor privind traducerea rămîne relativ mic" (Kohn, 1998, p. 540).

De curînd a apărut un studiu privind „ideile și metaideile traductive românești” (Lungu Badea, 2013), urmărite de-a lungul a nu mai puțin de șase secole, unde putem citi un diagnostic oarecum diferit de cel dat de Kohn, și nu mai puțin categoric. În capitolul privitor la „orientările actuale”, capitol concentrat pe perioada „postdecembristă”, deci practic pe ultimii 25 de ani, Georgiana Lungu Badea constată mai întîi puternicul impuls dat activităţii de traducere din spațiul românesc de unele „instituții culturale internaţionale, cît și de tendința de mondializare”, care ar fi declanșat, după dînsa, prin ricoșeu, și un proces de „reglementare a aparatului critic” (Lungu Badea, 2013, p. 125) utilizat de teoriile traducerii, în care include și lucrările unor cercetători de origine română, dar care s-au format și își desfăşoară activitatea în alte cadre academice decît cele din spațiul românesc (Ioana Popa, Ecaterina Cleynen-Serghiev, Iulia Mihalache), ceea ce nu o împiedică însă să tranșeze problema unei eventuale specificități a traductologiei românești: „Deși nu se poate vorbi despre o tradiție a disciplinei riguros teoretice a traducerii în spaţiul românesc, contribuțiile teoretice aduse de cercetătorii români—traducători și lingviști-sînt numeroase și variate” (p. 109). Autoarea va pune ulterior-explicit și oarecum tardiv—sub semnul unei întrebări mai curînd retorice (p. 132-133) $)^{2}$ însăşi capacitatea operațională a unui concept precum cel de „traductologie românească”.

\footnotetext{
${ }^{2}$ Titlul capitolului anterior, „Orientări în cercetarea traductologică românească”, devine astfel caduc.
} 
Cele două verdicte, exprimate de ambii cercetători cu egală convingere, privind specificul sau nonspecificul traductologiei românești sînt despărțite de cel puțin un deceniu și jumătate, interval de timp în care studiul academic al traductologiei s-a extins masiv, cu mare rapiditate, în întregul învățămînt universitar românesc și la toate nivelurile sale (licență, masterat, doctorat, proiecte ample de cercetare), interesînd și chiar captivînd categorii de specialiști tot mai mult largi, lucru dovedit de numărul considerabil de volume și studii publicate de ei în acest răstimp, dar și de apariția unor reviste exclusiv dedicate acesteia: dacă este să dăm crezare celor două opinii, am putea deduce că extinderea și consolidarea domeniului nu ar fi determinat și o consolidare a unui specific autohton ci, dimpotrivă, l-ar fi subminat pe cel existent în anii '90, diluîndu-l într-un proces de „globalizare” și „mondializare” a cercetării. Pe de altă parte, nu este foarte clar în ce anume ar consta acel proces de „reglementare a aparatului ei critic” despre care vorbește autoarea. În măsura în care, cum vom arăta în continuare, majoritatea lucrărilor ce-l utilizează în prezent sînt redactate în alte limbi decît limba română, acest proces nu s-a putut de fapt produce.

Pentru a examina întemeierea celor două puncte de vedere m-am oprit la două momente care mi s-au părut deosebit de fertile în gîndirea românească cu privire la traducere, ambele dinainte de 1989, pentru a le confrunta apoi cu situația de după 1990.

\section{Anii '60 ai secolului trecut}

În anii '60 ai secolului trecut, apariţia în Franța a lucrării intitulate Problèmes théoriques de la traduction semnată de Georges Mounin (carte ce nu a fost nici pînă în prezent tradusă în românește) a declanșat o vie dezbatere privind rolul gîndirii teoretice asupra traducerii, publicată în renumita revistă „Secolul XX”, în două numere consecutive (1 și 2, din 1965). În ambele numere ale revistei se pronunță asupra lucrării marelui lingvist și traductolog francez personalităţi ale vieții culturale a vremii, însă nu totdeauna cei cu o formație filologică solidă. Participă la dezbatere personalități eclectice ale vieții culturale românești, precum Marcel Breslașu, poet, fabulist, compozitor, interpret de lieduri, cronicar muzical, avocat și traducător, cîțiva ani redactor-șef al prestigioasei reviste „Secolul XX”, unde a publicat și cîteva traduceri; o personalitate complexă, alcătuită din tulburătoare jocuri de umbre (Șerban, 2011).

Al doilea text este semnat de Jacquier $(1965)^{3}$, cel care l-a acuzat pe Roland Barthes de pierderea cetățeniei franceze, ceea ce l-ar fi condamnat implicit să-și continue cariera și viața în România pînă la moarte (1980; v. Matei, 2014); autor al unei teze de doctorat în lingvistică, profesor de liceu și apoi universitar specializat în respectivul domeniu, Jacquier asumă o poziție atipică printre celelalte voci care se pronunță pe marginea cărții lui Mounin, deși începe prin a sublinia cît de „anevoioasă” este munca traducătorului, care trebuie să fie ,în același timp bun cititor și bun scriitor”. Declară însă, foarte tranșant, că „grupul conținuturilor sau al limbajelor științifice și tehnice [...] se bucură de traductibilitate integrală în orice limbă din lume”, întrucît se întemeiază pe „enunțuri univoce” și nu pe „exprimări afective”, „iar structura intelectuală a omului este la fel sub toate meridianele, deși se exprimă felurit” (Jacquier, 1965, p. 153), afirmații ce vădesc și un crez neclintit, de sorginte franceză, în universalitatea spiritului uman.

În loc să examineze însă postulatele de tip lingvistic și incidența lor în chestiunea traducerii, Jacquier pronunță un înflăcărat rechizitoriu de tip eseistic la adresa lingviștilor și a noilor lor teorii (nu scapă de dezaprobarea sa nici structuralismul de sorginte saussuriană în special, nici behaviorismul bloomfieldian, glosematica lui Hjelmslev sau distribuționalismul lui Harris, nici neo-kantienii precum Cassirer, ocazie de a demonstra și că este la curent cu respectivele curente), care, în loc să ,încurajeze” munca traducătorilor, nu fac altceva decît să o „osîndească la tăcere” (Jacquier, 1965, p. 155), ca și cum aceștia nu și-ar dori altceva decît ca omul „să rămînă închis în solitudinea individului chircit în sine, victimă desemnată a angoasei inexprimabilului” (p. 155). Captivat de propriul stil, Jacquier continuă în acelaşi registru, neuitînd să îi invoce constant pe traducători, pe care validitatea sau caducitatea teoriilor lingvistice îi lasă de altfel „indiferenți” (p. 155): teoria devine astfel, în viziunea lui, nu doar inutilă, ci şi dăunătoare, singurul lucru demn de reținut fiind existența de facto a traducerilor și superioritatea activității traducătorilor. Jacquier

\footnotetext{
${ }^{3}$ Sub același titlu va fi publicat în 1991 un volum îngrijit de Mircea Muthu, apărut la editura Dacia din Cluj-Napoca.
} 
nu face diferența de nivel dintre teorie, privită cu mare suspiciune, și practica propriu-zisă, traducătorul fiind condamnat să-și îndeplinească misiunea civilizatoare sub amenințarea lingvisticii, al cărei țel pare a fi doar cel de a „stînjeni la maximum îndeletnicirea” sa (p. 157).

Jacquier acceptă însă necondiționat valabilitatea tezei imposibilității traducerii atunci cînd vine vorba de poezie, caz în care, spune el, doar edițiile bilingve ar putea să-l ajute pe cititor să descopere esența textului original; în plus, astfel de ediții trebuie să cuprindă neapărat un „portret” al limbii originalului (cu referiri la fonetismul ei, la grafie, la gramatică), dînd „cît mai numeroase” note explicative, însoțite de traduceri secvențiale multiple (p. 160). El nu ratează nici ocazia de a se referi la etica traducătorilor, și enumeră în încheiere calităţile bunilor traducători, odată ce „s-au împăcat cu gîndul că traducerea literară este o muncă de aproximație”“" : probitate, modestie, mîndria unei meserii ce contribuie la „ridicarea intelectuală și la desfătarea sufletească a mii și mii de oameni, dar și la apropierea morală a popoarelor” (p. 160), întrun cuvînt, la constituirea literaturii universale. Mai presus de toate, traducătorul trebuie să-și continue misiunea civilizatoare „fără să se lase tulburat de verdictele pronunțate de unii lingviști, nici de sirenele absurdului cu armonioasele lor tînguieli despre angoasa inefabilului, singurătatea conștiinței individuale lipsite de comunicare cu ceilalți, și eșecul final inevitabil al limbilor” (p. 160).

În numărul următor, Nicolae Argintescu-Amza, critic literar, eseist, sociolog, filozof, pasionat de arte plastice (autor al unei lucrări despre Vermeer și al alteia despre Grigorescu), de estetică şi psihologie, cronicar de artă, traducător din Shakespeare, Horațiu, Lucrețiu, Baudelaire, Schiller, Molière, Claudel, Maiakovski, Pavese, atacă „dezinvoltura” lui Mounin, vizibilă, pune el, încă din titlul primei sale cărți, pe care acesta ar fi încercat să o compenseze ulterior printr-un „exces contar”, dînd „o excesivă audiență problemelor de strictă filologie modernă, în cadre cît mai doctorale” (Argintescu-Amza, 1965, p. 157). Ocazie de a regreta „formalismul” „unei bune părți din cercetările lingvistice” (p. 157), de a lansa o diatribă la adresa exceselor lor şi de a se teme ca nu cumva o „falsă interpretare lingvistică a procesului de traducere” să amîne „cu încă foarte mulți ani elucidarea acestui extraordinar mijloc de culturalizare mondial” (p. 158), și anume traducerea. Or, „elucidarea” despre care vorbește el ar trebui lăsată în seama psihologiei, care are a determina „treptele psihice”, altfel spus aptitudinile traducătorului, îndreptățit să producă, precum un Arghezi, „traduceri chiar superioare originalului” (p. 159). Una peste alta, păcatul de neiertat al cărții lui Mounin rămîne acela că ,principiul, poate fundamental, al procesului de traducere, nu este nici măcar amintit" (p. 160) și anume faptul că traducerea este un act interpretativ: prin urmare, ne îndeamnă autorul, mai bine ar fi să „depășim specificitățile falacioase ale fixismului”, „vădite cochetării ale unei anumite «filozofări» lingvistice” (p. 160), tot așa cum „trebuie depășită falsa aparatură științifică” (p. 161): pe scurt, necesară ar fi o lucrare intitulată „Probleme practice ale traducerii de artă”, epurată de „tehnicisme înguste”, pentru că, ultim avertisment, în „cercetările tinzînd spre obiectivitatea științifică”, „excesul iraţional al purismului” nu doar este „sterp”, dar poate „rătăci mintea” (p. 163).

La textele celor doi se adaugă și un altul, adesea invocat și în prezent, semnat de poetul, eseistul și traducătorul Ștefan Augustin-Doinaș, reputat pentru traducerea lui Faust de Goethe, a poemelor lui Hölderlin, dar și a unor texte de Mallarmé, Paul Valéry, Martin Buber, Giovanni Papini etc. (ar fi tradus din peste 10 limbi!): el dezvoltă o pledoarie apăsată, cum o arată și titlul, consolidată de o argumentație cu referințe la cîteva surse teoretice occidentale, în favoarea „posibilității” traducerii: textul său se încheie prin invitația înțeleaptă adresată traducătorilor de a „dovedi practic că «miracolul» traducerii poetice există”, lăsînd în seama „altora” „explicația, fundamentarea teoretică a posibilităţii” acestuia (Doinaş, 1965, p. 167).

Pentru aceste personalități culturale, ocupînd poziţii variate în cîmpul simbolic românesc al vremii, însă toate beneficiind de „vizibilitate”, cartea lui Mounin este mai degrabă un pretext pentru a se pronunța despre calitatea traducerilor, despre planuri editoriale, decît despre necesitatea dezvoltării în spațiul românesc a gîndirii teoretice privitoare la traducere. Breslașu (1965) recunoaște această lipsă de interes teoretic, dar îi acordă cîteva rînduri de încheiere, mai degrabă de complezență, subliniind că vede în teoria traducerii un „adjuvant” pentru cel ce se iniţiază în „vastul și complexul domeniu al literaturii universale” (p. 150).

4T̂ntr-o altă epocă, Paul Ricœur, și nu doar el, avea să vorbească despre „echivalență fără adecvare”. 
Tradiția românească în privința traducerii pare astfel a se dezvolta în cadrul unei tematici recurente de tipul „cum l-am tradus pe...” (aluzie la Blaga, 1957), „tălmăcindu-l pe...” (Porumbacu, 1951) și „arta de a traduce" (începînd cu Vianu, 1956, sau Cassian, 1981). Că reflecția asupra traducerii era văzută ca făcînd parte din literatura comparată, estetică sau istoria literaturii nu are a ne mira într-un moment în care nici formula Translation Studies, nici cea franceză, traductologie, nu fuseseră încă inventate. Reținem însă că toți cei ce se pronunță pe marginea cărții lui Mounin, fie ei scriitori, traducători sau lingviști împărtășesc, cu toate lecturile lor în domeniu aduse la zi, o egală reținere vizavi de rolul lingvisticii și, în general, al teoriei, în gîndirea asupra traducerii și un egal interes pentru practica traducerii cu toate componentele sale, însă doar a traducerii textului literar, traducerea altor tipuri de texte fiind total ignorată, pur și simplu ca nefiind traducere, ci transpunere mecanică a unor terminologii ${ }^{5}$.

\section{Anii ' 80 ai secolului trecut}

În primii ani ai deceniului ' $80 \mathrm{~s}$-au produs mai multe evenimente direct legate de reflecția privitoare la teoria traducerii, concentrate în cîteva publicaţii de mare circulaţie. În luna iunie a anului 1980 a avut loc un mare Colocviu național de traduceri și literatură universală $\breve{b}^{6}$, iar stenograma lucrărilor a fost publicată anul următor într-un număr special al revistei „Viața Românească”, intitulat Colocviul național de traduceri şi literatură universală (VR 1981); apoi, în 1983, numărul 1 al revistei, nu mai puțin renumite în acea epocă, „Cahiers roumains d'études littéraires”, a fost în întregime consacrat temei Poïétique/Poétique de la traduction (CREL 1983), și tot în acel an apărea și lucrarea lui Ioan Kohn la care m-am mai referit (Kohn, 1983); cu doi ani mai devreme, la începutul anului 1981, apăruse Orizontul traducerii al lui Gelu Ionescu (Ionescu, 1981a), cuprinzînd un foarte consistent text introductiv, a cărui valabilitate teoretică este și astăzi neatinsă.

Deși teoria se înzestrase între timp cu un nume propriu (în anii 1972-1976), iar textele pe care leam invocat pentru a încerca să delimitez centrele de interes din anii ' 80 vădesc din nou o bună corelare a lecturii autohtone cu ceea ce se scria și publica în sincronie în spaţiul european, ele rămîn în continuare axate pe chestiunea fidelității textului țintă vizavi de textul sursă în cadrul cuplurilor de limbi, pe fundalul aceleiaşi neîncrederi în abordările de tip lingvistic și, prin ricoșeu, pe contabilizarea diverselor tipuri de erori produse în procesul traducerii. Faptul este oarecum de înțeles în cazul opiniilor exprimate de participanții la Colocviul național de traduceri și literatură universală, majoritatea traducători, dar el este evident și în cazul textelor publicate în CREL 1983, unde multe studii poartă semnătura unor cercetători de formație academică.

Ioana Popa sugerează o posibilă explicație a concentrării dezbaterilor pe tema libertății și/sau a fidelității în traducere, particularitate pe care dînsa o regăsește în spațiul sovietic și apoi în întreaga zonă esteuropeană. Dat fiind că, printre scriitorii interziși, mulți erau autorizați să semneze și să publice traduceri, este posibil, spune cercetătoarea, ca ei să fi văzut în această activitate o „șansă acordată creaţiei, care ar fi putut influența modul lor de a traduce” (Popa, 2013, p. 28), deci să fi fost înclinați, ca să spunem aşa, congenital, spre traducerea liberă; pe de altă parte, mai observă dînsa, în anii '30, astfel de dezbateri erau, în orice caz, „politizate” în spațiul sovietic, iar „unii cercetători au văzut în preferința oficială pentru traducerea liberă un factor ce a favorizat cenzura și intervențiile asupra textelor sursă” (p. 28). Cu alte cuvinte, deși discuția asupra raportului dintre cele două texte în procesul traducerii ar fi fost frămîntată de tendințe și influențe contradictorii, balanța ar fi înclinat, din rațiuni subiective și ideologice, înspre valorizarea infidelităţii. Argumentația nu se verifică, după părerea mea, în spațiul românesc, în orice caz nu în perioadele la care mă refer eu aici (Ionescu, 1981b, p. 36) ${ }^{7}$. Majoritatea celor care abordează subiectul

\footnotetext{
${ }^{5}$ Argintescu-Amza (1965, p. 162) declara tranșant că „[...] nici traducerea de colportaj a textelor tehnice sau de vulgară vulgarizare nu pot avea nimic de-a face cu traducerea artistică”, iar Storch (1981, p. 72) anticipa, pe un ton la fel de categoric, „rolul important al computerelor”, care vor „traduce foarte bine un text științific care se bazează pe noțiuni și ecuații”.

${ }^{6}$ A se reține calificativul național, care trimitea în acea perioadă la multiple sensuri legate și de ideologia comunistă.

${ }^{7}$ Autorul observă și el fenomenul, limitîndu-l la perioada proletcultistă, cînd „mulți scriitori nu-și publică operele lor—sau
} 
se pronunță categoric pentru respectarea criteriului fidelității, ba chiar pun la îndoială abilitatea poeților de a transpune marile texte poetice ale literaturii universale: traducerile lui Tudor Arghezi, de pildă, sînt marcate de „prea puternica lui personalitate poetică”, ceea ce l-a împiedicat „să înțeleagă spiritul unui autor străin” (Covaci, 1981, p. 14).

Se fac însă auzite și unele voci, foarte puține, precum cea a lui Alexandru Balaci-dînsul ar dori întemeierea unei estetici a traducerilor care „,ă-și propună să elucideze [...] în ce constă esența muncii de traducere, a traducătorului” (Balaci, 1981, p. 74) —și, mai ales, cea a lui Gelu Ionescu, care deploră lipsa unei teorii coerente, fapt, mai spune el, ce ar explica și faza de amatorism în care s-ar complace în continuare însăşi practica traducerii: pentru prima dată, cu această intensitate, este afirmată necesitatea unor dezvoltări teoretice, iar „inexistența aparițiilor teoretice” este văzută ca o „consecință a aceleiași mentalități artizanale care patronează majoritatea traducătorilor noștri” (Ionescu, 1981b, p. 89). Peste alte cîteva rînduri, autorul insistă din nou și afirmă necesitatea teoriei și ca instrument formator al practicii: „nu ne putem lipsi de stimularea unei activităţi cu pronunțat caracter teoretic privind problemele traducerii” (p. 89) ce ar putea fi încurajată și prin traducerea unor texte de această factură, care să constituie cadrul necesar unei depăşiri a acestui „mirific stadiu artizanal” (p. 89) și să ducă la dezvoltarea unei „conștiințe teoretice, științifice, profesionalizate” (p. 89-90) în această direcție. În acest scop, el militează, asociinduse aici și altor voci (Verzea, 1981, p. 50; Lăzărescu, 1981, p. 94; Eliade, 1981, p. 94), și pentru necesitatea unei critici a traducerilor, nici în prezent măcar conturată (și nu doar în spațiul românesc), care să iasă din rubricile canonice ale criticii de întîmpinare și să întreprindă o adevărată analiză tehnică, „aplicată la detaliile cele mai fine ale unei tălmăciri” (Ionescu, 1981a, p. 52; 1981b, p. 89). Aceste deziderate le va susține, argumentîndu-le pe larg, și în prefața la cartea sa despre „orizontul traducerii”, în care reflecția asupra traducerii este însă aşezată în cadrul istoriei literaturii române contemporane, de unde, spune el, ea „absentează aproape cu totul”, alocîndu-i-se practic rolul de „anexă a fenomenului literar original” (Ionescu, 1981a, p. 9). Două sînt direcțiile de cercetare care ar putea contribui, după el, la reconsiderarea poziției traducerilor: examenul receptării lor în cultura română și, pe de altă parte, elaborarea unei teorii a lecturii (p. 11-15), din a cărei perspectivă, de pildă, fenomenul traducerilor ,întîrziate” ar putea explica şi modul în care literatura originală „reasimilează” trecutul, pregătind noi orientări sau întărind altele, incipiente, potențîndu-le. Autorul reia din nou ideea necesarei teorii a traducerii, în care vede o şansă acordată traducătorilor de a dobîndi o „conștiință teoretică superioară” (p. 29).

Elementul de continuitate în care văd eu specificul reflecției românești și care leagă cele două momente pe care le-am extrapolat aici constă în clara delimitare de teorie și, cum am spus, în rezistența față de aceasta, privită cu destulă neîncredere: este și trăsătura care a „scutit” reflecția românească de a efectua vreo reconsiderare față de „mirajul” lingvisticii, care a determinat în spaţiul vestic european atîtea revizuiri, dar a făcut posibilă și construirea traductologiei ca demers autonom. Concomitent, reflecția asupra practicii a depăşit, atît la nivel cantitativ, cît și calitativ, pe cea privind teoria, cum rezultă și din ceea ce Irina Mavrodin a numit și încercat să fundamenteze încă din anii '80, și anume o „practico-teorie” (Mavrodin, 1983).

Este nu mai puțin adevărat și că acest „specific” s-a dezvoltat pe un teren fertil: în spațiul românesc, reflecția asupra literaturii este puternic marcată de o tradiție impresionistă, eseistică (a cărei culme a constituit-o Istoria literaturii a lui George Călinescu), care a împins nu de puține ori tentativele pur teoretice într-o postură de auto-justificare. Se mai remarcă astfel, lucru ce se verifică pe termen lung, încă o situație oarecum paradoxală: pe de o parte, autorii textelor la care m-am referit pînă acum, dar și a multor altora pe care nu am socotit necesar să le analizez aici, erau la curent cu ce se scria în marile limbi de circulație în domeniul traductologiei, nemanifestîndu-se vreo evidentă rămînere în urmă, și, pe de alta, ei manifestau o tenace rezervă, o reticență, metamorfozată uneori în refuz explicit, fie ei scriitori, eseiști, poeți sau specialiști, vizavi de necesitatea construirii unei teorii. Chiar și CREL 1983, unde se pronunță un număr consistent de „universitari”, este axat pe aceeaşi confuzie de nivel hermeneutic între practică și teorie: Irina Mavrodin, responsabila numărului și autoarea textului introductiv, care, într-un anume fel,

publică doar o parte din ce scriu—și astfel se ocupă de traduceri: efect «pozitiv» al unei situații regretabile”. 
dă și tonul în abordarea tematicii, începe prin a declara că „O traducere reușită nu are cum să rezulte din aplicarea mecanică a vreunei teorii, oricît de adecvată ar fi ea, pentru că teoria, prin chiar generalitatea ei, nu se aplică lesne la traducere [...]. Traducerea este, înainte de toate, o practică [...]” (Mavrodin, 1983, p. 4): ca și cum teoria și practica ar urmări același scop!

Traducerea este prin urmare corelată cu literatura însăși, iar chestiunea literalităţii și a fidelității ocupă din nou locul central în dezbatere, teoria fiind obligată să se pronunțe din perspectivă contrastivă și stilistică: Victor Ivanovici declară că „este de la sine înțeles că am adoptat perspectiva contrastivă a stilisticii lingvistice [...]" (Ivanovici, 1983, p. 11). După ce constată, nu neapărat ca pe un eveniment pozitiv, că „bibliografia privind traducerea cunoaște o proliferare dramatică” (este vorba de anii '80!) și enumeră cel puțin trei tipuri de abordări teoretice, ,adesea în dezacord” (p. 34), Pop-Corniș (1983) își propune să „analizeze în ce măsură au afectat ele atît teoria românească a traducerii, cît și practica traducerii și, la un nivel și mai dramatic, traducerea poeziei românești în limbi de circulație" (p. 35-56), pentru a ajunge la concluzia că ele joacă un rol (negativ), în măsura în care au încercat să-i determine pe traducătorii de poezie români „să se conformeze atît formei, cît și ideilor”, într-o indecizie ce îşi lasă amprenta asupra traducerii, provocînd, nu de puține ori, exact „efectul opus” (p. 41) asupra receptării.

Tema receptării literaturii române în Occident este una recurentă, uneori cu tente naționaliste: impunerea ei în circuitul mondial depinde de conștientizarea faptului că „principiul universalității este obligat să depindă de cel al traductibilității" (Pop-Corniş, 1983, p. 36), iar vocile care se pronunță în favoarea traducerii în tandem (Eliade, 1981, p. 93; Ralea, 1981, p. 86), un traducător român și un traducător vorbitor nativ al limbii țintă, sînt nenumărate; la fel și multitudinea studiilor și luărilor de poziție privind analiza traducerilor operelor literare românești în limbile de circulație ${ }^{8}$, chiar dacă ea intra, pentru unii, în capitolul „propagandei peste hotare” (Munteanu, 1981, p. 60). Nici în acest caz, ca și în privința traducerilor în limba română, opinia generală nu favorizează traducerea liberă și nici nu vede scriitorii și poeții ca pe cei mai potriviți traducători (Covaci, 1981, p. 14): Leon Levițchi invocă, în luarea sa de cuvînt, o „comisie Shakespeare”, fondată în anii 1950 și alcătuită din personalităţi de primă mărime ale culturii române, comisie ce a „legiferat niște puncte de vedere românești privind îndatoririle fundamentale ale traducătorului onest", unanim aprobate de plenul Uniunii Scriitorilor, din care cel puțin șapte insistă asupra următoarelor „norme”: traducerea să fie integrală, să fie făcută din limba originalului, „să nu supraliciteze”, să nu se facă „vinovată” de „păcatul omisiunii” (Levițchi, 1981, p. 72) ${ }^{9}$. Franz Storch îi invita, la rîndul său, pe traducători să nu cumva să vadă în traducere „o frumoasă care strălucește prin infidelitatea sa” (Storch, 1981, p. 72); Alexandru Balaci asimilează arta traducerii cu fidelitatea, sarcina traducătorilor constînd în a reda „cît se poate de fidel [...]”, în a „transmite conținutul integral [...]” (Balaci, 1981, p. 73-74), iar lista celor cu opinii similare s-ar putea oricînd extinde.

\section{Traductologia la cumpăna dintre secole: 1995-2014}

Fractura istorică, ideologică și politică de după 1989 a modificat radical ideea de continuitate și a antrenat chiar un refuz al preluării vreunei tradiții. Totodată, după 1995 se produce treptat și instituționalizarea traductologiei: în jurul anilor 2000, se înființează, în practic tot învățămîntul universitar, secții de traductologie la nivel de licență; apar apoi masterate specializate în traductologie și interpretariat, ceea ce

\footnotetext{
${ }^{8}$ La Colocviul național de traduceri și literatură universală practic toți participanții exprimau dorința ca literatura română să fie difuzată în lume. Din cele patruzeci și două de intervenții, treizeci și trei se pronunță explicit pe această temă: Aurel Covaci, p. 16; George Potra, p. 19; Edgar Papu, p. 20; Lörinczi Làszlò, p. 22; Tatiana Nicolescu, p. 25; Constantin Crișan, p. 29; Corneliu Barborică, p. 31; Andrei Brezianu, p. 39; Maria Banuș, p. 42; Florin Murgescu, p. 45; Petre Solomon, p. 49; Ileana Verzea, p. 50; Cristina Petrescu, p. 52; Balogh Iózsef, p. 53; Florian Potra, p. 56; Romul Munteanu, p. 60; Dan Grigorescu, p. 65; Ștefan Augustin-Doinaș, p. 68; N. Carandino, p. 71; Franz Storch, p. 72; Alexandru Balaci, p. 4; Radu Lupan, p. 76; Paul Alexandru Georgescu, p. 77; Cristea Chelaru, p. 82; Alexandru Paleologu, p. 84; Catinca Ralea, p. 87; Zoe DumitrescuBușulenga, p. 90; Marin Mincu, p. 92; Irina Eliade, p. 94; George Lăzărescu, p. 95; Iulian Neacșu, p. 97; Micaela Slăvescu, p. 99; Andrei Bantaş, p. 104.

' $̂$ În același număr, mulți alții (cf. Busuioceanu, 1981, p. 62 etc.) vorbesc despre erori de traducere şi invocă implicit dezideratul fidelității și al rigorii în traducere.
} 
Magda Jeanrenaud

determină elaborarea unui mare număr de lucrări de licență și disertație axate pe acest domeniu. Numărul doctoratelor din domeniul traductologic sporește an de an (deși nici procedura de admitere în Școlile doctorale și nici cursurile din primul an, desfăşurate în cadrul a două module, literar și lingvistic, doctoranzii care au ales teme traductologice pentru lucrarea de doctorat înscriindu-se majoritar în modulul lingvistic, nu acceptă decît tacit o specializare strict traductologică). Se înmulțesc colocviile și manifestările ştiințifice consacrate traductologiei, iar majoritatea celor de tip „generalist”, filologic, cuprind și ele secții dedicate acesteia. Apar și două reviste, consacrate exclusiv reflecției traductologice, care dobîndesc treptat o anumită reputație în cîmpul simbolic. Cercetarea, impulsionată de cîștigarea prin concurs a unor mari proiecte europene și naționale, antrenează întregi echipe de cercetători, contribuind la specializarea lor în respectivul domeniu. Circulația ideilor nu se mai face doar prin cea a cărților, contactele directe se înmulțesc prin prezența în diverse comisii de abilitare, doctorate, concursuri pe post, dar și prin diverse programe de mobilitate, de tip Erasmus sau Ceepus, atît a cercetătorilor, cît și a studenților. Temele perioadei anterioare (accentul pe practică, discuția în jurul fidelității, distanțarea vizavi de teorie, militantismul vizînd pătrunderea pe piața internațională) dispar sau se diluează puternic odată cu instituţionalizarea domeniului traductologic, și aceasta din cel puțin două cauze: pe de o parte, sincronizarea cu reflecția europeană, care consolidase deja noile domenii de investigare a traducerii-act și proces-, devenite teoretic autonome sub denumirile știute, și ale căror tematici sînt preluate și studiate în noile module și secții acreditate în învățămîntul superior, pe de alta, o rezervă de natură ideologică, odată cu prăbușirea sistemului comunist, care a generat și o neîncredere, chiar un dezinteres vizavi de axele de reflecție ale perioadei anterioare, uneori chiar cu ignorarea însăși existenței lor.

Deschiderea aceasta către spațiul occidental antrenează și o schimbare de direcție în configurația centrelor de interes și, pînă la urmă, chiar în formarea tinerilor cercetători, tot mai interesaţi de evoluția marilor teorii elaborate în spațiul occidental, dar și de căile cele mai oportune de pătrundere rapidă în cîmpul simbolic conturat la „centru”. La „fractura” dintre un ,înainte” și un „după” s-au mai adăugat alte două elemente, cu efect conjugat, de natura să dilueze pînă la dispariție unele tradiții specifice spațiului românesc: pe de o parte, procesul de globalizare și mondializare, inclusiv în cîmpul simbolic, pe de alta, poziția „marginală” a limbii și culturii române față de limbile și culturile de mare circulație. Așa se explică probabil trecerea de la tradiția „practico-teoriei” întrevăzută, în anii '95, de Kohn, la lipsa oricărei tradiții specific românești, diagnosticată de Lungu Badea (2013): cele două opinii nu se contrazic, ci înregistrează pur și simplu două stări de lucruri generate de două momente istorice diferite. Încît analiza sociologică efectuată de Gisèle Sapiro cu privire la compoziția pieței mondiale a traducerilor, prin definiție „asimetrică”, unde fluxul traducerilor se mișcă de la centru spre periferie din perspectiva raportului între limbile sursă și limbile țintă—engleza ocupînd o poziție „hiper-centrală”, germana, franceza și rusa o poziție „centrală”, alte cîteva una „semi-periferică”, în timp ce restul, ce acoperă mai puțin de $1 \%$ din piața traducerilor, una „periferică” (Sapiro, 2012b, p. 33)—, poate fi extinsă și la circulația fluxurilor teoretice, și ele puternic influențate de limbile și culturile unde se dezvoltă, care se înscriu astăzi pe aceleași direcții cu sens aproape unic: „Globalizarea a încurajat unificarea pieții mondiale a traducerii și a intensificat schimburile, dar nu a favorizat diversitatea culturală măsurată prin numărul limbilor sursă ale cărților traduse" (Sapiro, 2012b, p. 37). Concluzia mea este că, odată cu explozia lucrărilor de traductologie, presiunea „centrului” sau a „centrelor” europene și anglo-saxone s-a produs fără a întîmpina vreo „rezistență” provenită dintr-o tradiție autohtonă (inexistentă în materie de teorie) și a antrenat inclusiv dispariția specificității perioadei anterioare (accentul pe practică), dar nu a înlesnit conturarea alteia. Explicaţiile sînt multiple: voi sintetiza doar cîteva, care mi se par mai evidente.

Secțiile de traductologie, impropriu reunite în toate universitățile românești sub numele generic LMA (limbi moderne aplicate) oferă o dublă specializare, în traductologie și în două limbi străine (specializarea A și B), astfel încît studenții care au una din specializări în limba română nu au acces la aceste programe de studii. Rămîne practic la latitudinea profesorilor dacă ea se strecoară sau nu în unele materii, însă nu face obiectul unor studii structurate. Înainte ca domeniul numit „Competențe de comunicare” să reunească diverse cursuri practice de traduceri, conversație, redactare, exista, de pildă, un curs practic de traduceri 
interlingvistice, în care studentul dobîndea competențe traducînd dintr-una din limbile studiate direct în cealaltă, fără vreo trecere prin limba maternă.

Cursurile teoretice, printr-o tradiție ce datează cel puțin de după cel de-al doilea război mondial, se țin în limbile în care studentul se specializează, adică cele două limbi străine: studentul audiază (și urmează a fi evaluat în traductologie) două cursuri cu această titulatură, unul ținut în engleză, celălalt în franceză, dacă acestea sînt limbile sale de studiu. Compartimentate în acest fel, desigur că se creează ideea că există o traductologie „franceză”, una „engleză”, și așa mai departe. Lucrările de licență, ca și cele de disertație sînt elaborate și susținute în fața unei comisii în limba principală a studiilor. Abia la nivel de masterat este posibil să se înscrie studenți care au urmat o combinație de studiu de tip limba engleză-limba română, însă aceștia vor fi, cel puțin inițial, mult dezavantajați față de studenții care provin din secțiile LMA și care au deja o bază traductologică ce le lipsește celor dintîi. Ajunși în față elaborării unei teze de doctorat, acești tineri vor opta în mare parte pentru redactarea lucrării în limba în care li s-au predat materiile teoretice, ceea ce le ușurează mînuirea aparatului conceptual, a cărui transpunere în română mulți nu o cunosc (şi aici este vorba de ansamblul noțiunilor de limbă dobîndite pe tot parcursul școlarizării) sau o cunosc aproximativ (atunci cînd ea există) (v. Lungu Badea, 2013, p. 125).

Această veche tradiție a învăţămîntului universitar românesc în formarea specialiștilor în limbi moderne nu a fost, după știința mea, niciodată contestată, cu atît mai mult cu cît, în prezent, orice modificare ar determina restrîngerea drastică a numărului studenților străini doritori să urmeze cursurile de la facultățile de Litere în cadrul programelor europene de tip Erasmus sau Ceepus. Ironia face că marile concursuri de traducători pentru Uniunea Europeană, patronate de EPSO (European Personnel Selection Office) cu sediul la Bruxelles, după primele sesiuni, în care candidații susțineau doar probe de traducere între două limbi (dintre care una era cea maternă), a introdus și probe de gramatică a limbilor materne: or absolvenții secțiilor de traductologie din spațiul românesc, specializați în franceză-engleză, de pildă, nu dispun de nici o bază teoretică sau competențe de comunicare dezvoltate în limba lor maternă (poate cu excepția limbajelor specializate) pe parcursul studiilor universitare.

În România, există două reviste exclusiv consacrate traductologiei: una apare în limba franceză, cealaltă în mai multe limbi de circulație, mai puțin limba română. Impactul lor în crearea și asimilarea echivalențelor conceptuale în limba română nu poate deci juca un rol decisiv; pe de altă parte, dacă ele pătrund astfel pe piața internațională, în schimb nu înregistrează o circulație masivă pe piața românească, în orice caz nu sînt foarte prezente în presa literară și de specialitate românească ${ }^{10}$.

Foarte optimistă, viziunea lui Mircea Vultur privind raportul dintre „globalizarea culturală”, definită ca un proces de „diseminare a culturilor în lume”, și ceea ce el numește „societățile est-europene de dimensiuni mai mici”, rezultă și din perspectiva în care s-a poziţionat sociologul canadian, examinînd fenomenul dinspre „centru”, fără a rezolva în prealabil o sumă de contradicții teoretice. De fapt, el vede în extinderea influențelor dinspre „centru” spre „periferie” un fenomen inevitabil, susținut practic nu doar „dinafară”, ci mai ales „dinăuntru” (nota bene!), de însuși mecanismul actual al evoluției mentalităţilor culturilor est-europene, unde „teama de americanizarea lingvistică și de dominația limbii engleze nu constituie o îngrijorare serioasă” (Vultur, 2002, p. 195). Din această perspectivă, însăşi afirmația sa privind răspîndirea culturilor în lume apare ca fiind dezechilibrată de tendința, tot de el constată, de omogenizare provocată de supremația celei răspîndite de limba engleză. Într-adevăr, așa cum susţine autorul, nici în prezent, la 25 de ani de la prăbuşirea regimului comunist, intelectualii nu privesc statul cu încredere (p. 195), ceea ce a determinat, prin ricoșeu, devalorizarea noțiunii de ,identitate colectivă”, percepută ca o barieră în calea modernizării, întruchipată de hegemonia culturală americană (p. 197).

Situația această se reflectă masiv în situația domeniului traductologic, așa cum apare el în statistica publicațiilor. Fișierele Bibliotecii Universitare din Iași privind subiectul „traductologie” cuprind 176 fișe bibliografice privind perioada 1993(5) pînă în prezent (decembrie 2014). Am clasificat fișele în: dic-

\footnotetext{
${ }^{10}$ „Atelier de traduction”, revistă semestrială de „teorie și analiză a traducerii în limba franceză”, Universitatea „Stefan cel Mare”, Suceava (fondată în 2004); „Translationes”, „revistă plurilingvă de traducere și traductologie”, Universitatea de Vest Timișoara, un număr pe an (primul a apărut în 2009).
} 
ționare de traductologie, cărți străine în original, cărți străine traduse în română, cărți de autori români publicate în limbi străine, cărți de autori români publicate în limba română, teze de doctorat, articole publicate în reviste și periodice, cărți rezultate din publicarea unor conferințe cu tematică traductologică. Analiza lor scoate în evidență cîteva trăsături esențiale ale reflecției traductologice actuale din spațiul românesc:

1. în această perioadă au fost publicate două dicționare (unul beneficiind de cel puțin două reeditări);

2. numărul cărților străine scrise de autori străini este foarte redus, 11 volume, alcătuind un corpus deosebit de eterogen (3 volume germane, 4 franceze, restul anglo-americane), prezența lor în rafturile bibliotecii datorîndu-se probabil unor donații;

3. numărul cărților cu tematică traductologică care au fost traduse în română este deosebit de mic: 7 , dintre care 1 din greacă, 1 din spaniolă, 1 din italiană, 1 din franceză, 3 din engleză (dintre care una datează din 1983, After Babel de G. Steiner);

4. s-au publicat în această perioadă 22 de volume în limba română scrise de autori români (excluzînd reeditările);

5. s-au publicat în schimb 50 (excluzînd reeditările) de volume semnate de autori români, scrise în limbi străine și publicate la edituri românești: 1 în rusă, 1 tipărită cu caractere chirilice, 1 în spaniolă, 1 în italiană, 2 în germană, 17 în limba franceză, 27 în limba engleză;

6. volumele au apărut majoritar la edituri mici și la edituri universitare, unele dintre ele fiind cursuri sau manuale pentru uzul studenților (două adresate elevilor);

7. în fine, pătrunderea autorilor români pe piaţa internaţională în traducere este deosebit de redusă: am înregistrat doar doi autori români care au fost publicați în traducere în spațiul european, doi de către edituri franceze, dintre care unul și de către una germană.

Se remarcă un accentuat dezechilibru între producția de carte publicată în limba română și cea în alte limbi, printre care limba engleză este de departe cea mai utilizată. Faptul duce-cred că a și dus-la o „preluare” a tradițiilor occidentale fără ca interesul ancorării lor în cultura autohtonă să se manifeste în vreun fel; fenomenul explică și lipsa de terminologii conceptuale românești sau fluctuațiile lor de la un autor la altul ceea ce înseamnă că ele nu s-au putut deocamdată consolida în limba română. Autorii acestor cărți sînt în mare parte profesori sau cercetători universitari și faptul că preferă să-și publice cărțile (uneori pe propria cheltuială) direct într-o limbă de circulație internaţională are legătură în primul rînd cu modul de predare în tot sistemul universitar umanist, dar și, poate, cu o dorință, mai degrabă irealistă, de a pătrunde astfel pe piața cărții străine mai repede. Aceste cărți nu se pot adresa unui public autohton mai larg, receptarea lor depinzînd strict de limbile pe care le cunosc cititorii, fie ei universitari, critici literari sau chiar teoreticieni ai traducerii. Nici studenții de la secțiile de traductologie nu au acces la ele decît în măsura în care stăpînesc limba în care este scrisă cartea, de unde și o puternică fragmentare a cunoașterii, care rămîne închisă în limba în care au fost scrise textele, cînd ar fi putut fi vehiculată tocmai de limba maternă a autorilor, ceea ce ar fi facilitat considerabil intrarea lor într-un circuit național. Fractura reverberează și în mediul traducătorilor, care, deși au și ei opiniile lor teoretice privind traductologia, devin tot mai „invizibili”, întemnițați în propriile lor limbi de lucru și cu acces limitat la textele care vorbesc tocmai despre profesiunea lor: se insinuează astfel și ideea cum că tocmai limba lor maternă, limba țintă, devine şi ea tot mai „invizibilă”.

Această stare de lucruri justifică, cred, următoarea ipoteză: specificul actual al teoriilor traductologice în spaţiul românesc decurge din existența a două circuite, unul academic și internaţional, care urmărește înscrierea cercetării românești în direcțiile conturate la nivel european, asimilîndu-le mai mult sau mai puțin, și altul, intern, în care pozițiile exprimate în cadrul celui dintîi pătrund indirect, prin intermediul limbilor „centrale” și se manifestă sub forma unor afinități selective și elective, între cele două interacțiunea făcîndu-se sporadic, și mai ales prin intermediul altor limbi, și nu printr-un proces de interiorizare legat de limba spațiului gazdă.

Din acest punct de vedere, ar merita să reflectăm asupra îmbogățirii semantice și deschiderii culturale pe care limba franceză o oferă (și) datorită modului în care a fost tradus termenul englez globalization, 
prin mondialisation; odată cu introducerea, în lexicul francez, și a termenului globalisation, a fost posibilă o interesantă nuanțare semantică, care a făcut ca acești doi termeni să nu fie sinonime perfecte. Dat fiind că termenul francez mondialisation admite antonime și variante derivate (alter- și anti-), el conotează și pluralismul, eterogenitatea. Prognozele excelent sintetizate de Oustinoff (2011, p. 153-165) și care sînt bazate pe faza actuală a mondializării, fază prin excelență culturală (Wolton, 2003, apud Oustinoff, 2011, p. 154, 155, 159), pariază, odată cu Declarația universală a UNESCO privind diversitatea culturală (2001), pe multilingvism, pe pluralitatea limbilor "care este prima realitate politică a lumii contemporane” (p. 101). Doar astfel se poate modera europocentrismul și salva diversitatea culturală, cu atît mai mult cu cît se produc în prezent la nivel mondial fenomene noi, legate de transferul de tehnologii către societățile mai puțin dezvoltate, care, la rîndul lor, încep să le dezvolte și să le transfere către alte societăți, iar acest transfer nu se mai face printr-o limbă vehiculară, ci prin intermediul limbilor „locale” (p. 168). Există semne că am începe să ieșim din faza în care era necesară dobîndirea unei singure limbi, engleza, și ne îndreptăm deja spre cea a plurilingvismului (p. 169) ${ }^{11}$, după cum o dovedește și Ghidul pentru elaborarea politicilor lingvistice educaționale în Europa, insuficient discutat în spațiul public românesc.

\section{Concluzii}

Înainte de a încheia, aș dori să vă împărtășesc și o dilemă, să spunem, de ordin în același timp metodologic și epistemologic, în măsura în care însăși poziționarea dinăuntru a celui ce se pronunță, practic în sincronie, asupra existenței sau a non-exsitenței unei tradiții (naționale) mi se pare problematică. Poate că poziția „dinăuntru” a cercetătorului, atunci cînd formulează judecăți de ansamblu nu este totdeauna și cea mai în măsură să îl ajute să întrevadă liniile de forță după care evoluează un fenomen cultural: lipsindu-i și o necesară distanţă în timp pe lîngă cea în spațiu, el poate risca să se aventureze în afirmații globalizante, uneori provenite dintr-o poziționare defectuoasă vizavi de faptele investigate. Cu alte cuvinte, cred în virtuțile epistemologice ale exotopiei, aşa cum a definit-o Todorov (1982) în continuarea lui Mihail Bahtin, văzînd în ea o șansă acordată cunoașterii de tip hermeneutic, și a dialogului în care se angajează doi parteneri la modul ideal egali. Dialogul dintre un subiect provenit „dinafara” și unul „dinăuntru”, însă ambii posedînd competențe egale în materia asupra căreia se pronunță mi se pare că ar fi idealul unei dezbateri pe teme precum cea aflată în discuție aici.

La Iași are loc, de doi ani, un festival ce poartă numele FILIT (Festivalul internațional de literatură şi traducere) care a dobîndit foarte rapid o recunoaștere internațională, reunind anual pentru aproape o săptămînă, nume dintre cele mai renumite printre scriitorii români și străini, dar și pe traducătorii lor. Festivalul propune mese rotunde, discuţii între traducători, ateliere de lucru, interviuri cu scriitori și traducătorii lor şi chiar şi conferințe pe teme teoretice: nu este, poate, întîmplător, că într-una din mesele rotunde organizate în acest cadru s-a auzit, anul trecut, o voce care s-a întrebat de ce s-o fi chemînd „literatură și traducere”, căci, în fond, „traducerea este literatură”... Dincolo de pseudo-butadă (dacă va fi fost vorba de o butadă și nu de altceva) transpare aici și rezistența „tradițională” vizavi de teorie despre care am vorbit, dar și tenacitatea ei, pentru că ea a fost rostită de însuși președintele Uniunii scriitorilor din România, cunoscut drept unul dintre cei mai importanți critici literari și autor al unei monumentale şi mult discutate Istorii critice a literaturii române.

Parcă pentru a „scuza” propria convingere privind inexistența unei tradiții traductologice românești, Georgiana Lungu Badea se întreabă retoric dacă „compartimentarea traductologiei în diviziuni naționale” are vreun „rost”, dacă este „utilă” și „funcțională”, dacă o tipologizare „naționalizantă” (Lungu Badea, 2013, p. 133; termenul este pus în ghilimele de autoare, sic) are vreo utilitate: oricum, mai spune dînsa, ar însemna să ne întrebăm concomitent și dacă există o traductologie franceză, germană, americană, italiană etc. Răspunsul nu poate fi, desigur, decît categoric afirmativ, gîndirea asupra traducerii s-a dezvoltat pretutindeni în strînsă legătură cu evoluția limbii, a literaturii şi a culturii unui anumit spaţiu. Autoarea mai pare a sugera și că orientările și direcțiile specifice unui spațiu național nu fac neapărat specificitatea acestuia,

\footnotetext{
${ }^{11}$ Iar elitele (franceze) care pariază doar pe engleză, mai spune Oustinoff, au rămas pur și simplu în urmă.
} 
pentru că ele nu „exclud interesul” pentru „alte aspecte ale cercetării traductologice” (p. 134; este vorba de ultimul paragraf al lucrării): în ce mă privește, cred că tocmai acel interes pentru o „practico-teorie” făcea parte din specificul traductologiei românești, ca și dezbaterea obsesivă despre fidelitate-libertate în contextul perioadei de dinainte de 1990 și că ele s-au pierdut sub presiunea „centrului” sau „centrelor”, de unde au venit alte tematici, față de care cercetătorii au dorit/trebuit să se poziționeze. Tot așa cum nici traducerile nu sînt „inocente”, tot astfel nici abordările teoretice nu sînt cu desăvîrșire „neutre”, ci, cum arăta Gentzler (2013), „adînc implicate în politicile de putere”12.

Cum spune textul semnat de Jacques Derrida pe care l-am așezat ca motto la aceste reflecții, nici o teorie nu este independentă de limba care o exprimă, iar cine spune limbă spune și cultură. Nu este întîmplător că spațiul românesc nu a produs (încă) o mare teorie într-ale traducerii: faptul are o legătură şi cu lipsa altor teorii fondatoare, cu neîncrederea în însăși capacitatea unei teorii de a înlesni cunoașterea. Tot așa cum nu este întîmplător că teoriile funcționaliste s-au dezvoltat mai mult în spațiul german decît în cel francez: tradiția, găzduită de limbile romanice, de a vedea în traducere mai degrabă o trădare, nu s-a dezvoltat în spațiul germanic, unde traducerea are mai degrabă a face cu preluarea tradiției. Poate și de aceea entuziasmul pentru teoria skopos-ului este acolo mai mare, neavînd a gestiona suspiciunea față de o transmitere axată masiv pe funcția textului. Tot așa cum tratarea temei literalismului, în spațiul francez, de către Antoine Berman sau Henri Meschonnic, are de-a face cu un secol și mai bine de totală credință în frumusețea infidelităţii.

Modul cum evoluează teoriile în cîmpul științelor umane este fără doar și poate dependent de limbile și culturile în care se dezvoltă ele: ele sînt produsul unor subiecți, la rîndul lor dependenți nu doar de însușiri personale, ci și de mediul, epoca, cultura în care s-au format. Iar direcțiile de cercetare se conturează și ele, nu doar în funcție de un circuit academic și, ca atare, internaţional, dar și de unul intern, mai puțin vizibil. Nu este indiferent dacă o teorie apare într-o cultură și limbă de circulaţie restrînsă sau într-una de circulație internaţională, tot așa cum nu este indiferent dacă ea apare într-o societate „monolingvistică”, într-una „plurilingvistică” sau într-una postcolonială: altfel se va manifesta „presiunea” unei asimilări sau conformări la influențele venite dinspre „centru”.

\section{Bibliografie}

Argintescu-Amza, N. (1965). Despre «Frumoasele credincioase», în „Secolul XX”, nr. 2.

Baillargeon, J.-P. (ed.) (2002). The Handing Down of Culture, Smaller Societies and Globalization, Presses de l'Université de Laval.

Baker, M. (ed.) (2000). Routledge Encyclopedia of Translation Studies, Routledge, New York, ed. I, 1998.

Baker, M. \& van Doorslaer, L. (ed.) (2000). Routledge Encyclopedia of Translation Studies, Routledge, New York, ed. I, 1998.

Baker, M. \& Saldanha, G. (ed.) (2011). Routledge Encyclopedia of Translation Studies, Routledge, New York, ed. II, 2009, CrossRef.

Balaci, Al. (1981). Colocviul național de traduceri și literatură universală, în vR 1981, p. 74.

Berner, Chr. \& Milliaressi, T. (ed.) (2011). La traduction: philosophie et tradition. Interpréter/traduire, Presses Universitaires du Septentrion, Villeneuve d'Ascq.

Blaga, L. (1957). Cum am tradus pe Faust, în „Steaua”, nr. 8, 5 mai.

Breslașu, M. (1965). Probleme teoretice ale traducerii: pe marginea unei cărți de Georges Mounin, în „Secolul XX”, nr. 1.

Busuioceanu, O. (1981). Colocviul național de traduceri și literatură universală, în VR 1981, p. 62.

Cassian, N. (1973). Arta de a traduce, în „Secolul XX”, nr. 1, p. 146-148.

CREL 1983 = „Cahiers roumains d'études littéraires”, nr. 1, Poïétique/Poétique de la traduction, Univers, București, 1983.

Covaci, A. (1981). Colocviul național de traduceri și literatură universală, în vR 1981, p. 14.

Cronin, M. (2003). Translation and Globalization, Routledge, New York.

Derrida, J. (1998). Psyché. Inventions de l’autre, în Des Tours de Babel, Galilée, Paris.

Doinaș, Șt.-A. (1965). Dificil, riscant, dar nu imposibil, în „Secolul XX”, nr. 2, p. 164-168.

van Doorslaer, L. \& Flynn, P. (ed.) (2013). Eurocentrism in Translation Studies, John Benjamins, Amsterdam, CrossRef. Eliade, I. (1981). Colocviul național de traduceri și literatură universală, în VR 1981, p. 94.

\footnotetext{
${ }^{12}$ Înseși variațiile din sfera semantică a termenului „traducere” în marile și mai puțin marile culturi ale lumii pe care le examinează dînsul scot în evidență strînsa legătură între un spațiu cultural și modul cum este privită la un moment sau altul al istoriei activitatea de traducere.
} 
Flynn, P. (2013b). How Eurocentric is Europe? Examining scholars' and translators' contributions to translation studies - an ethnographic perspective, în van Doorslaer \& Flynn (2013), p. 62-77.

Gambier, Y. \& van Doorslaer, L. (eds.) (2012). Handbook of Translation Studies, vol. 3, John Benjamins, Amsterdam, CrossRef. Gambier, Y. \& van Doorslaer, L. (eds.) (2013). Handbook of Translation Studies, vol. 4, John Benjamins, Amsterdam, CrossRef. Gentzler, E. (2013). Macro- and micro-turns in translation studies, în van Doorslaer \& Flynn (2013), p. 9-28.

Gile, D. (2012). Institutionalization of Translation Studies, în Gambier \& van Doorslaer (2012), CrossRef.

Hermans, T. (ed.) (2002). Crosscultural Transgressions. Research Models in Translation Studies. II. Historical and Ideological Issues, Routledge, New York, CrossRef.

Hermans, T. (2014). Translating Others, vol. 1, 2006, vol. 2, 2012, Routledge, New York; ed. I, St. Jerome Publishing, 2006.

Ionescu, G. (1981a). Orizontul traducerii, Univers, București.

Ionescu, G. (1981b). Colocviul național de traduceri și literatură universală, în VR 1981, p. 89.

Ivanovici, V. (1983). Text and Translatability, în CREL 1983, p. 11.

Jacquier, H. (1965). Babel, mit viu, în „Secolul XX”, nr. 1, 1965, p. 151-160.

Kohn, I. (1983). Virtuțile compensatorii ale limbii române în traducere, Facla, Timișoara.

Kohn, J. (1998). Romanian Tradition, în Baker \& van Doorslaer (2000), p. 539-541 .

Lăzărescu, G. (1981). Colocviul național de traduceri și literatură universală, în VR 1981, p. 94.

Levițchi, L. (1981). Colocviul național de traduceri și literatură universală, în VR 1981, p. 54-55.

Londei, D. \& Callari Galli, M. (ed.) (2011). Traduire les savoirs, Peter Lang, Berna.

Lungu Badea, G. (2013). Idei şi metaidei traductive românești (secolele XVI-XXI), Editura Eurostampa, Timișoara.

Matei, Al. (2014). Fîntîna barthesiană. Cazul Henri Jacquier și două păcate mortale, în „Observator cultural”, nr. 719.

Mavrodin, I. (1983). La traduction - une pratico-théorie, în CREL 1983.

Munteanu, R. (1981). Colocviul național de traduceri și literatură universală, în VR 1981, p. 60.

Oustinoff, M. (2011). Traduire et communiquer à l'heure de la mondialisation, CNRS Editions, Paris.

Popa, I. (2013). Communism and Translation Studies, în Gambier \& van Doorslaer (2013), CrossRef.

Pop-Corniș, M. (1983). Romanian Poetry in an Age of Translation, în CREL 1983, p. 34-41.

Porumbacu, V. (1951). Tălmăcindu-lpe Scipaciov, în „Viața românească”, nr. 4, 7 iulie, p. 198-216.

Pym, A., Schlesinger, M. \& Simeoni, D. (2008). Beyond Descriptive Translation Studies: Investigation in Homage to Gideon Toury, John Benjamins, Amsterdam, CrossRef.

Ralea, C. (1981). Colocviul național de traduceri și literatură universală, în VR 1981, p. 86.

Sapiro, G. (ed.), Traduire la littérature et les sciences humaines. Conditions et obstacles, Ministère de la Culture et de la Communication, Paris.

Sapiro, G., Editorial policy and translation, în Gambier \& van Doorslaer (2012), CrossRef.

Storch, F. (1981). Colocviul național de traduceri și literatură universală, în VR 1981, p. 72.

Șerban, G. (2011). Meandrele memoriei. Breslaşu vs Bresliska, în „Observator cultural”, nr. 560, ianuarie.

Todorov, Tz. (1982). Comprendre une culture: du dehors/du dedans, în „Extrême Orient”, Paris.

Verzea, I. (1981). Colocviul național de traduceri și literatură universală, în VR 1981, p. 50.

Vianu, T. (1956). Ceva despre arta traducerii, în Literatura universală și literatură națională, ESPLA, p. 267-278.

VR 1981 = „Viața Românească”, număr special, Colocviul național de traduceri și literatură universală, revistă editată de Uniunea scriitorilor, București, 1981.

Vultur, M. (2002). Cultural Globalization ans Smaller Eastern European Societies, în: Baillargeon, J.-P. (ed.), The Handing Down of Culture, Smaller Societies, and Globalization, Presses de l'Université de Laval, p. 192-199.

Wolton, D. (2003). L'autre mondialisation, Flammarion, Paris (apud Oustinoff, 2011). 